\title{
The biological effects of chemical contaminants in the Arabian/Persian Gulf: A review
}

\author{
Zenaba Khatir ${ }^{\mathrm{a}}$, Alexandra Leitão ${ }^{\mathrm{a}}$, Brett P. Lyons ${ }^{\mathrm{b}, *}$ \\ ${ }^{a}$ Environmental Science Center (ESC), Qatar University, P.O. Box 2713, Qatar \\ ${ }^{\mathrm{b}}$ Cefas Weymouth Laboratory, Barrack Road, The Nothe, Weymouth, DT4 8UB, UK
}

\section{A R T I C L E I N F O}

\section{Article history:}

Received 16 July 2019

Received in revised form 5 November 2019

Accepted 5 November 2019

Available online 9 November 2019

\section{Keywords:}

Biological effects

Chemical contamination

Toxicology tests

Cellular, biochemical and histological

biomarkers

Arabian/Persian Gulf

\begin{abstract}
A B S T R A C T
The Arabian Gulf is a shallow sea naturally exposed to extreme conditions of temperature and salinity due to its location, semi-enclosed nature, bathymetry and restricted circulation. Compared to open marine systems, the added stress imposed by pollutants is likely to have additional adverse consequences. Maintaining good marine environmental quality is crucial for several socio-economic reasons, one of the most important being that the region relies heavily on seawater as a source of freshwater through desalination. While regionally based marine monitoring programs employing chemical endpoints have been widely deployed, few have evaluated the potential biological effects of those contaminants detected. However, it is now widely recognized that an integrated approach using both chemical measurements and appropriate biological endpoints in key sentinel species is essential to the design and implementation of marine environmental programs. Here we present an exhaustive review of the studies published so far in the Gulf on the biological effects of chemical contaminants using different biological endpoints and suggest potential areas requiring additional research.
\end{abstract}

(c) 2019 Elsevier B.V. All rights reserved.

\section{Contents}

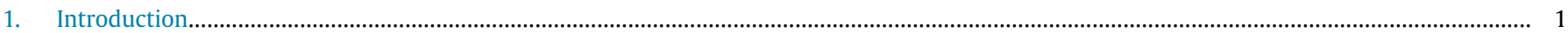

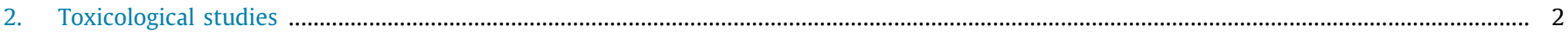

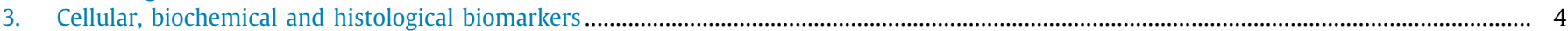

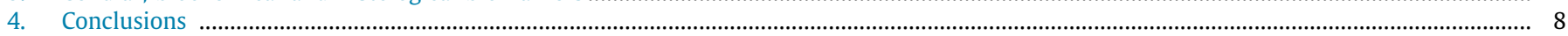

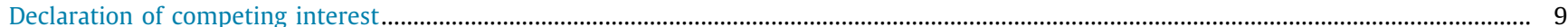

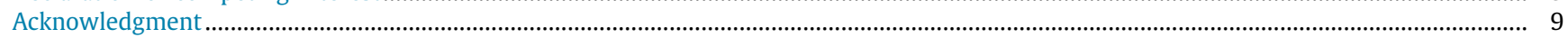

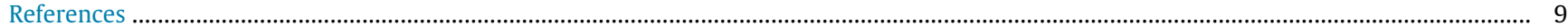

\section{Introduction}

The Arabian Gulf (also known as the Persian Gulf and hereafter referred to as the Gulf) is located at the Southwestern corner of Asia, an extension from the Gulf of Oman (Fig. 1) (Subba and Al-Yamani, 1998; Pous et al., 2012). The Gulf is a shallow sea naturally exposed to extreme conditions due to its location, semienclosed nature, bathymetry and restricted circulation (Sheppard et al., 2010; Sale et al., 2011; ROPME, 2013). Average summer sea surface temperature can reach $33^{\circ} \mathrm{C}$ and fluctuations between winter and summer values can be as much as $20{ }^{\circ} \mathrm{C}$ (Bjerkeng and Molvær, 2000; Sheppard et al., 2010). Freshwater mainly enters the Gulf in the Northern most section, via the Shatt AlArab, which is formed by the confluence of the Euphrates and

\footnotetext{
* Corresponding author.

E-mail address: brett.lyons@cefas.co.uk (B.P. Lyons).
}

the Tigris rivers. Due to upstream dam construction and water extraction for agriculture the volume of freshwater flowing down the Shatt Al-Arab has drastically reduced in recent years (AlYamani et al., 2017). This coupled with high evaporation rates and poor flushing via the Strait of Hormuz, results in mean salinities exceeding 40 psu across many parts of the Gulf with shallow embayment's, such as the Gulf of Salwah, between Bahrain, Qatar and Saudi Arabia reaching as high as 70 psu (Sheppard et al., 2010; Al-Said et al., 2017; Al-Yamani et al., 2017). Yet despite these harsh conditions the Gulf contains regionally important sea grass habitats, coral reefs and mangroves (Sheppard et al., 2010; Erftemeijer and Shuail, 2012; Burt et al., 2014), which are home to species of global conservation significance, including elasmobranchs, hawksbill turtles and dugongs (Moore et al., 2013; Pilcher et al., 2014; Marshall et al., 2018). The Gulf is also of societal and economic importance to countries bordering its waters, providing food and drinking water (via desalination) along 
with supporting tourism and recreational activities (Van Lavieren et al., 2011; ROPME, 2013).

The oil exploration and exploitation processes that started in the last century has driven industrial and economic development across the region, leading to a rapid rise in urbanization along its coastal margins (Sheppard et al., 2010; Van Lavieren et al., 2011). The human population of Gulf countries has grown from 46.5 million to nearly 150 million since the early 1970 s and is estimated to reach 200 million by 2030 (ROPME, 2013; United Nations, 2017). More than $85 \%$ of the expanded population, in five of the Gulf countries, Bahrain, Kuwait, Oman, Qatar, United Arab Emirates (UAE), live within close proximity to the coast (Van Lavieren et al., 2011). While economically and socially valuable, this growth has come with an associated environmental cost and the Gulf's marine environment now faces many pressures (Sheppard et al., 2010). These include eutrophication (Devlin et al., 2019), inputs of domestic sewage (Lyons et al., 2015b; Saeed et al., 2015), discharges of industrial waste, including brine from the vast network of desalination plants (Naser, 2013; AlSarawi et al., 2015) and the resuspension of sediment and habitat loss, due to the significant amounts of coastal construction that has taken place in recent years (Sheppard et al., 2012; Sheppard, 2016). A number of studies have now described hot spots of contamination, particularly by petroleum hydrocarbons and metals in sediments and waters near industrial sites (de Mora et al., 2004; Naser, 2014; Soliman et al., 2014; Al-Sarawi et al., 2015), along with a small but growing body of evidence documenting the presence of so called 'emerging contaminants', including those with endocrine disrupting (Smith et al., 2015; Saeed et al., 2017; Al-Jandal et al., 2018) and antimicrobial activity (Al-Sarawi et al., 2018; Le Quesne et al., 2018).

Compared to open marine systems, the added stress imposed by pollutants is likely to have adverse consequences for the health of the Gulf's marine environment, as well as for food and drinking water security. Indeed, maintaining good marine environmental quality in the region is crucial for several socio-economic reasons, one of the most important being that the region relies heavily on seawater as a source of freshwater through desalination (Darwish and Mohtar, 2013). Currently desalination capacity in the region is drawing over 20 million $\mathrm{m}^{3}$ day $^{-1}$, which is predicted to reach 80 million $\mathrm{m}^{3}$ day $^{-1}$ by 2050 (Dawoud and Al Mulla, 2012; Burt et al., 2014; Dougherty et al., 2019). By 2050, if current predictions materialize, desalination in combination with climate change, will elevate coastal water temperatures across more than $50 \%$ of the Gulf by at least $3{ }^{\circ} \mathrm{C}$, with more than a third of the total volume of coastal water $(0-10 \mathrm{~m})$ passing through desalination plants each year (Burt et al., 2014; Dougherty et al., 2019). Discharges associated with desalination pose multiple threats to the receiving marine ecosystems with super saline water often containing contaminants such as metals, corrosion inhibitors and biocides introduced to prevent biofouling (Sheppard et al., 2010; Dawoud and Al Mulla, 2012).

The main leading regional marine management program in the Gulf is run under the auspices of the Regional Organization for the Protection of the Marine Environment (ROPME). The core program was started 40 years ago, and the results of more recent studies have been published in a series in integrated reports (AlMajed et al., 2000; ROPME, 2003, 2013). The reports assessed the state of the marine environment across the ROPME sea area (RSA) using a combination of water, sediment and biota chemistry. While chemical directed marine monitoring programs, such as those reported by ROPME, are widely deployed within the Gulf they are usually restricted to a narrow range of contaminants mainly linked to the region's oil and desalination industries (de Mora et al., 2004; Naser, 2013; ROPME, 2013; Al-Sarawi et al., 2015; Freije, 2015; Cunningham et al., 2019). The constraints of chemical only directed monitoring programs are now acknowledged (OSPAR, 2008; Viarengo et al., 2007; Wernersson et al., 2015; Vethaak et al., 2017). This includes issues such as the limited number of determinants that can be accurately quantified, an understanding of potential additive or synergistic effects and a lack of information on direct measurements of contaminant related biological effects in exposed fauna and flora (Van der Oost et al., 2003; Viarengo et al., 2007; Lyons et al., 2010). A biological effect is generally defined as the response of an organism, a population, or a community to changes in its environment (Van der Oost et al., 2003). It is now acknowledged that the assessment of environmental health, and the design and implementation of measures to improve environmental quality, are best undertaken on the basis of an integrated approach using both analytical chemistry and appropriate biological measurements (representing different levels of biological complexity, e.g. subcellular, tissue and whole organism) in key sentinel species (OSPAR, 2008; Law et al., 2010; Davies and Vethaak, 2012; Wernersson et al., 2015).

Due to the complexity of contaminants in the environment and the variety of responses that they induce in exposed organisms, it is important that multiple biological effects endpoints are assessed in marine monitoring programs (Van der Oost et al., 2003; Viarengo et al., 2007; Thain et al., 2008; Vethaak et al., 2017; Lyons et al., 2017). The usefulness of any biological-effect method will obviously depend on how well it is able to separate anthropogenic stressors from the influence of other unrelated biotic or abiotic factors. For example, it has been shown that hepatic 7-ethoxyresorufin-odeethylase (EROD) activity in fish, which is used as a biomarker of exposure to a range of organic contaminants, can also be influenced by ambient water temperature or stage of sexual development (Kammann et al., 2005), and may have its response modified by co-occurring contaminants (Kirby et al., 2007a). However, for most of the widely used methods there is sufficient understanding to allow for appropriate supporting data to be collected that allows an accurate assessment of contaminant effect to take place (Davies and Vethaak, 2012). When selecting biological effects-based endpoints to use in environmental monitoring programs it is also important to consider their sensitivity to contaminants, including the ability to distinguish a dose response and whether their detection is indicative of recent or long-term exposure (Van der Oost et al., 2003). There have been clear examples where biological effects techniques have been used to identify contaminant related problems in the marine environment and the subsequent success of management interventions. The most notable of these in recent years has been assessing the impact of the antifouling compound, tri-butyl tin (TBT) contamination, on marine gastropod molluscs (Rodríguez et al., 2009; Nicolaus and Barry, 2015; Schøyen et al., 2019) and the use of vitellogenin biomarkers (vtg) and reproductive organ histopathology to detect the impact of endocrine disrupting chemicals in fish (Matthiessen et al., 2002, 2018).

Until now, there has only been a limited number of published studies in the Gulf using biological effects tools and these have focused on toxicology tests that measure growth or mortality, with only a few studies employing other molecular, cellular and tissue level endpoints. As such it is timely to review the current status of contaminant related biological effects monitoring within the region. Here we highlight the methodology and bioindicator species used to date (Tables 1 and 2) and discuss areas requiring further research to support the wider application of biological effect tools in marine monitoring programs across the region.

\section{Toxicological studies}

There are now a series of well-established studies that document chemical contamination of the Gulf's marine environment, 


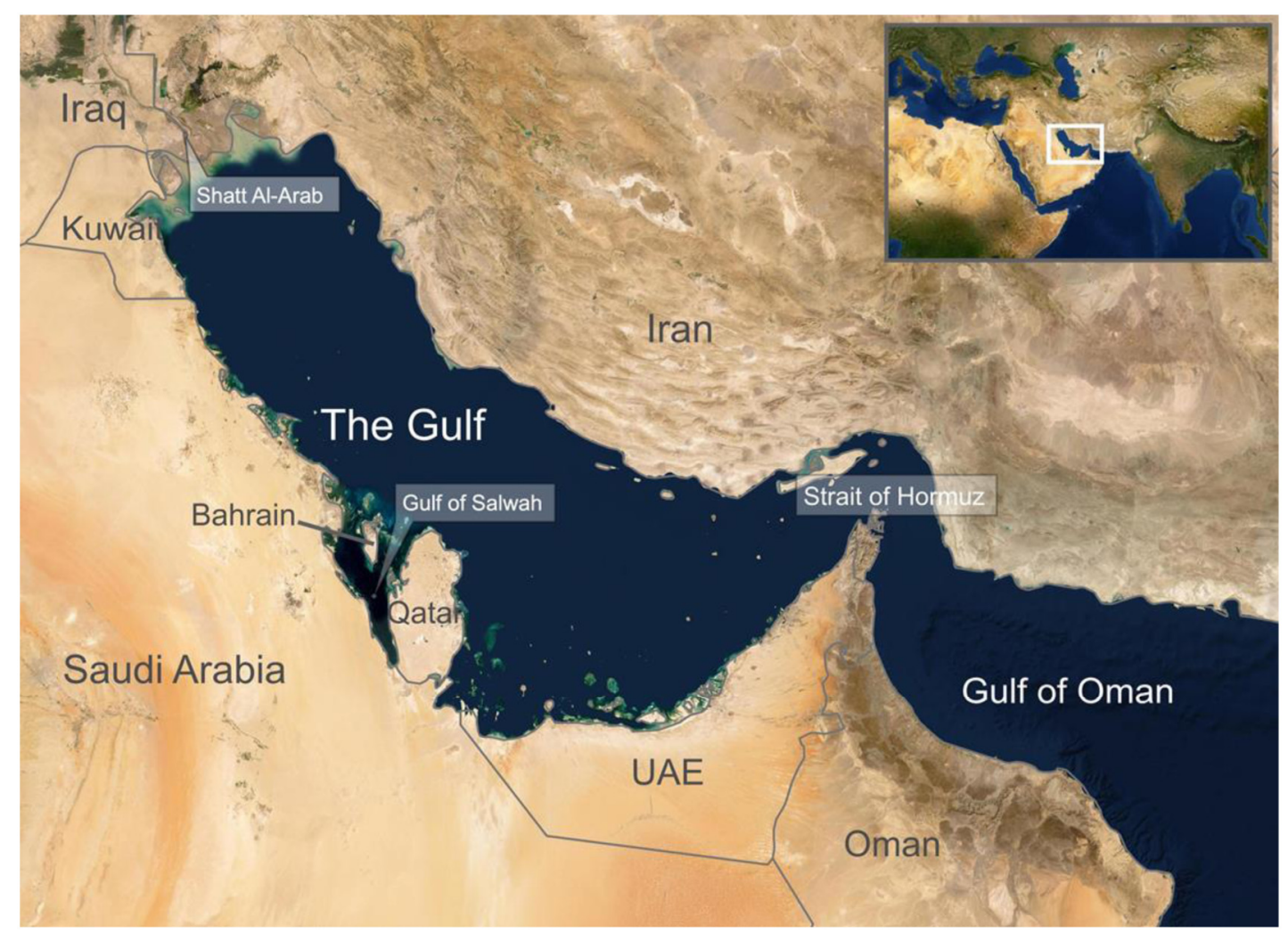

Fig. 1. Map of the Gulf and the surrounding states.

indicating that species inhabiting its waters are at risk from these potentially toxic compounds (de Mora et al., 2010; Naser, 2013; Freije, 2015; Cunningham et al., 2019). One of the first published toxicity studies in the Gulf was conducted by Jacob et al. (1980) which utilized local species of mullet Liza macrolepis, prawn Penaeus semisculcatus, gastropods Lunella coronatus, Monodonia canalifera, Thais fusconigra, Planaxis sulcatus, sea urchin Echinometra mathael and brine shrimp Artemia salina. Using these species in a range of short and long-term toxicity bioassays the median lethal concentrations $\left(\mathrm{LC}_{50}\right)$, when exposed to metals $(\mathrm{Cu}$, $\mathrm{Hg}, \mathrm{Pb}, \mathrm{Cd}$ and $\mathrm{Zn}$ ), chemical fertilizers, crude oil and fuel oil were determined. The data revealed marked differences in response between species, with the greatest sensitivity observed in tests where $\mathrm{Cu}$ and $\mathrm{Hg}$ were administered ( $\mathrm{LC}_{50}$, Table 2 ) (Jacob et al., 1980). The direct risk posed by oil spills either in isolation or in combination with the chemical dispersants, which are often used post-spill to disperse oil based contamination, have been subject to a number of laboratory-based studies in the region (Jacob et al., 1980; LeGore et al., 1989; Bordbar et al., 2006; Delshad et al., 2014; Karam et al., 2019). Findings demonstrate an increase in toxicity when dispersants and oil are tested in combination, compared to either dispersant or oil in isolation, in a number of test species including rainbow trout (Oncorhynchus mykiss) (Bordbar et al., 2006) and the commonly farmed shrimp species Litopenaeus vannamei (Delshad et al., 2014) (Table 2). Similar studies have also been conducted on the early life stages of fish species common to Gulf waters. Using the mullet fry (L. macrolepis) oil dispersants were tested under salinity and temperature regimes common across the Gulf region (El Samra et al., 1986). The $72 \mathrm{~h} \mathrm{LC}_{50}$ determined by the authors were far lower than those previously published for the dispersants tested, which was attributed to a combination of the sensitivity of the species used and local test conditions (temperature and salinity) employed. A range of dispersants, in isolation and in combination, with Kuwaiti crude oil have been assessed for toxicity using egg hatching and larval survival of commercially important Orange-spotted Grouper Epinephelus coioides (Karam et al., 2019). Test conditions again mirrored temperature (20$28{ }^{\circ} \mathrm{C}$ ) and salinity (40-42 psu) regimes encountered locally and highlighted the increase in toxicological risk to marine species if spilled oil is chemically dispersed. The toxic risk posed by the water-accommodated fraction (WAF) of Kuwait crude oil has also assessed in E. coicoides (Karam et al., 2014). Using both lethal and sub-lethal effects (larval deformities) it was observed that WAFs did not affect hatching success, but mortality and developmental malformations occurred post hatching within the $96 \mathrm{~h}$ test window ( $96 \mathrm{~h} \mathrm{LC}_{50} 0.48 \mathrm{~g}$ oil/l seawater). Again, the authors used test conditions that simulated commonly encountered environmental conditions. While the generation of such data is useful in a postspill scenario it also provides some indication of the risk posed by many of the chemical constituents of the WAF, with the authors suggesting that local (Kuwait) seawater contamination by petroleum based pollutants did not pose a serious toxicological risk to marine life (Karam et al., 2014).

The impact of oil and dispersant exposure on corals has been assessed in field-based studies along the Gulf coast of Saudi Arabia (LeGore et al., 1989). Corals were exposed to both $24 \mathrm{~h}$ and $120 \mathrm{~h}$ periods to Arabian light crude oil and Corexit 9527, either individually or in combination, at concentrations designed to mimic post-spill conditions. Subsequent growth rate observations were conducted at 3-month intervals for 1 year. Healthy corals were shown to tolerate these relatively short exposure periods with growth and colonization rates unaffected following the exposure regimes employed (LeGore et al., 1989). Only minor impacts were noted, with $5 \%$ of Acropora species exposed to dispersed oil unable to survive subsequent temperature stress brought on by the winter season. The impact of co-stressors, such as seawater temperature, is an important consideration especially in the Gulf where large differences (up to $20^{\circ} \mathrm{C}$ ) exist between summer highs and winter lows (Sheppard et al., 2010). 
The ability of corals in the region to tolerate oil exposure has also been demonstrated in studies that recorded minimal impacts on growth (via coring experiments) following major oil spill events in the region (Poulsen et al., 2006). Given the importance of corals as key regional ecosystems in the Gulf (Vaughan and Burt, 2016) such studies should continue to be a priority area for research.

To date, around half of the marine toxicology tests undertaken in the Gulf have been conducted in Kuwait. These include a series of studies which evaluated the commercially fished mullet species Liza klunzingeri as a potential locally relevant bioindicator species for chemical toxicity and bioaccumulation studies (Bu-Olayan and Thomas, 2005a,b, 2008; Bu-Olayan et al., 2008). Static renewal toxicity tests developed lowest observed effective concentration (LOEC) and $\mathrm{LC}_{50}$ data for a range of metals in short term $72 \mathrm{~h}(\mathrm{~Pb}, \mathrm{Ni}, \mathrm{V}, \mathrm{Cu}, \mathrm{Fe})$ (Bu-Olayan and Thomas, 2005a,b) and 96 h (Ni, Fe, Cd, As) (Bu-Olayan et al., 2008) studies. Further work using L. klunzingeri (Bu-Olayan and Thomas, 2008) and the Brine Shrimp, Artemia fransicana (Bu-Olayan and Thomas, 2006) evaluated the toxicity of biocides (formaldehyde, sodium hypochlorite and glutaraldehyde), which are commonly discharged from desalination and water-cooled industries in the region (Bu-Olayan and Thomas, 2006). Biocide specific 96 h LOEC and $\mathrm{LC}_{50}$ data were generated using a range of different dilution seawater samples, collected from locations around Kuwait. The LOEC and $\mathrm{LC}_{50}$ data produced differed depending on the source of dilution water, highlighting that seawater from some of the sites studied contained both biotic and abiotic factors that may sensitize test species to the biocides tested (Bu-Olayan and Thomas, 2006, 2008). The mudskipper, Periophthalmus waltoni has also been evaluated as a bioindicator species in both acute toxicity (96 h) and bioaccumulation (60 d) studies (Bu-Olayan and Thomas, 2008). Again, selecting commonly tested metals ( $\mathrm{Zn}$, $\mathrm{Cu}, \mathrm{Cd}$ and $\mathrm{Fe}$ ), $\mathrm{LOEC}$ and $\mathrm{LC}_{50}$ data were generated for P. waltoni along with tissue specific Bioaccumulation Factors (BAFs). Field collected phytoplankton have also been used to assess differences in response to metal toxicity $(\mathrm{Cu}, \mathrm{Ni}, \mathrm{Pb}, \mathrm{Zn})$, along with the inter-site variability in metal accumulation (Bu-Olayan et al., 2001). Studies have also found site of collection to influence the sensitivity of intertidal invertebrate species, blue crab Portunus pleagicus and the cockle Tapes sulcarius to $\mathrm{Hg}$ when subject to short-term laboratory based $96 \mathrm{~h}$ toxicity tests (Bu-Olayan and Thomas, 2015). Other studies in the region have demonstrated the suitability of locally isolated marine bacteria to be used as a sentinel species to assess the risk posed by metal toxicity (Chandy, 1999). Marine waters collected from coastal locations around Kuwait have been screened for toxicity using the Pacific Oyster Crassostrea gigas, $24 \mathrm{~h}$ embryo development test (Smith et al., 2015). Results indicated clear impact on embryo development in samples collected from effluent outfalls or coastal sites close to known point sources of pollution. Interestingly, some of the sites where these results were reported, would have passed routine water quality assessments if the assessments had relied only on chemical led monitoring programs, measuring metals and petroleum-based contaminants alone (Nicolaus et al., 2017).

Sediments are a known sink for chemical contaminants and the risk they pose to biota (either through direct contact or ingestion) is an important consideration when assessing the fate and effect of contaminants in the marine environment (de Mora et al., 2010; Hutchinson et al., 2013). Following the mass oil spills resulting from the aftermath of the 1991 Gulf War sediment samples were assessed for toxicity using the marine amphipod Rhepoxynius abronius (Randolph et al., 1998). Sites with sediments causing the greatest toxicity (reduced survival rates over 10 days) were observed to also contain the highest concentrations of petroleum hydrocarbons, with samples $>1 \mathrm{mg} \mathrm{g}^{-1}$ dry weight (total petroleum hydrocarbons), shown to induce significant amphipod mortality. Seawater containing resuspended sediment collected from locations close to industrialized facilities in Kuwait have also been shown to reduce the survival of tilapia (Oreochromis spilurus, Gunther) fingerlings in $96 \mathrm{~h}$ bioassay tests (Beg et al., 2001). The microtox solid phase toxicity (SPT) assay has also been used to screen sediments (Beg et al., 2001; Beg and Al-Ghadban, 2003) and sediment pore water (Beg et al., 2001). Results using the microtox SPT assay linked toxicity, to range of chemical pollutants detected in the sediment, suggesting that the degree of response was a function of the collective effects of the pollutants present in the sample (Beg et al., 2001; Beg and Al-Ghadban, 2003). Sediment pore water contained a lower concentration of chemical contaminants (reflecting the hydrophobicity of the sediment bound contaminants), and this was reflected in lower toxicity when screened with both the microtox SPT assay and brine shrimp larvae, A. salina bioassay (Beg et al., 2001). The use and development of standard protocols specific for species indigenous to the region is an important development, particularly as many of the standard test species (e.g. those used routinely in Europe or North America) will not be adapted to the high salinity and temperature found in the Gulf (Sheppard et al., 2010). While some of the studies listed above address this requirement there is still the need to increase the number of species across different taxa for which data is available, along with developing toxicity tests with reproductive or developmental endpoints to allow more accurate assessments of chemical risk to be undertaken. In addition, a co-stressor that to date has often been over-looked in region is the potential of UV light to enhance to toxicity oil-based contaminants (Wernersson, 2003). Data is available demonstrating that in laboratory studies WAFs generated from mechanically and chemically dispersed Kuwaiti crude have their toxicities significantly increased in the presence of environmental levels of UV light (Kirby et al., 2007b), and this is an area warranting further study under conditions simulating those commonly encountered in the Gulf's surface waters.

\section{Cellular, biochemical and histological biomarkers}

Along with the assessment of mortality, growth and development it is also important to consider sub-lethal biochemical and cellular markers, as valid endpoints when assessing the risk chemical contaminants pose to marine ecosystems (Van der Oost et al., 2003). To date, there are relatively few studies that have assessed their use and application to the Gulf's marine environment (Table 1). Common contaminants in the region, such as metals and hydrocarbons are known to pose a potential genotoxic risk even at low doses, with possibility of the transmission of those impacts to future generations (e.g. Bouilly et al., 2003; Barranger et al., 2015). Therefore, it is important to understand the risk such contaminants pose to marine organisms in monitoring programs, where biological effects-based tools are being employed (Hutchinson et al., 2013; Wernersson et al., 2015). Studies have used widely adopted in-vitro mutagenicity bioassays to screen extracts of sediments which had been previously contaminated by an oil spill (Sato et al., 1998). Employing the Ames tests two strains of Salmonella typhimurium (TA100 and TA98) were used to screen oil contaminated factions, which had been extracted from field collected sediment samples. Results indicate that extracts had a low mutagenic potential, despite in some cases of having significant PAH contamination (Sato et al., 1998).

Studies determining the impact of exposure to organotins (widely used as plastic stabilizers, pesticides and antifouling agents in marine paints) have also been undertaken using in-vitro liver homogenates of the common Gulf species Acanthopagrus latus and the rabbit fish Siganus canaliculatus (Al-Ghais et al., 2000). Data indicated that there was a clear enhanced ability of $S$. canaliculatus to detoxify xenobiotics by hepatic microsomal and 
Table 1

Summary of the available data on the biological responses to variant contaminants in the Gulf.

\begin{tabular}{|c|c|c|c|c|c|c|}
\hline No. & Biomarker & Origin & Biological model & Stressor & Method of analysis & Reference \\
\hline 1 & $\begin{array}{l}\text { Toxicological studies } \\
\text { (Toxicity test) }\end{array}$ & Iran & $\begin{array}{l}\text { Local rainbow trout } 0 . \\
\text { mykiss }\end{array}$ & $\begin{array}{l}\text { Oil dispersants (Pars1 and } \\
\text { Gamlen OD4000) }\end{array}$ & $\begin{array}{l}\text { Acute toxicity test for } \\
96 \mathrm{~h}\end{array}$ & $\begin{array}{l}\text { Bordbar et al. } \\
(2006)\end{array}$ \\
\hline 2 & $\begin{array}{l}\text { Toxicological studies } \\
\text { (Toxicity test) }\end{array}$ & Iran & $\begin{array}{l}\text { Local farmed penaeid } \\
\text { shrimp L. Vannamei }\end{array}$ & $\begin{array}{l}\text { Oil dispersants (IND Iranian } \\
\text { Naftroob crude oil, RD } \\
\text { Radiagreen OSD) and crude } \\
\text { oil }\end{array}$ & $\begin{array}{l}\text { Acute toxicity test for } \\
48 \mathrm{~h}\end{array}$ & $\begin{array}{l}\text { Delshad et al. } \\
\text { (2014) }\end{array}$ \\
\hline 3 & $\begin{array}{l}\text { Toxicological studies } \\
\text { (Toxicity test) }\end{array}$ & Kuwait & $\begin{array}{l}\text { Local mullet } L . \\
\text { macrolepis, prawn } P \text {. } \\
\text { semisculcatus, gastropods } \\
\text { L. coronatus, M. } \\
\text { canalifera, T. fusconigra, } \\
\text { and } P \text {. sulcatus, sea } \\
\text { urchin E. mathael and } \\
\text { shrimp A. salina }\end{array}$ & $\begin{array}{l}\text { Metals (copper, mercury, } \\
\text { lead, cadmium, zinc) }\end{array}$ & $\begin{array}{l}\text { Acute }(96 \mathrm{~h}) \text { and } \\
\text { chronic }(60 \text { days }) \\
\text { toxicity tests }\end{array}$ & Jacob et al. (1980) \\
\hline 4 & $\begin{array}{l}\text { Toxicological studies } \\
\text { (Toxicity test) }\end{array}$ & Kuwait & $\begin{array}{l}\text { Bacteria, purchased brine } \\
\text { shrimp eggs } A \text {. salina } \\
\text { and local fish } 0 . \text { spilurus }\end{array}$ & $\begin{array}{l}\text { Total organic carbon, } \\
\text { volatile organic matter, total } \\
\text { petroleum hydrocarbons, } \\
\text { polycyclic aromatic } \\
\text { hydrocarbons, cadmium, } \\
\text { chromium, copper, lead, } \\
\text { nickel, vanadium, and zinc }\end{array}$ & $\begin{array}{l}\text { Bacteria's EC; } \\
\text { Microtox Analyzer } \\
\text { Model } 500 \\
\text { shrimp larvae: acute } \\
\text { toxicity test for } 24 \mathrm{~h} \\
\text { fish assay: acute } \\
\text { toxicity test for } 96 \mathrm{~h}\end{array}$ & Beg et al. (2001) \\
\hline 5 & $\begin{array}{l}\text { Toxicological studies } \\
\text { (Toxicity test) }\end{array}$ & Kuwait & $\begin{array}{l}\text { Phytoplanktons (Diatoms } \\
\text { and dinoflagellas) }\end{array}$ & $\begin{array}{l}\text { Metals (copper, lead, nickel, } \\
\text { zinc) }\end{array}$ & $\begin{array}{l}\text { Atomic Absorption } \\
\text { Spectrophotometer } \\
\text { (AAS-Perkin Elmer } \\
5100 \text { ) and oxygen } \\
\text { evolution assessment }\end{array}$ & $\begin{array}{l}\text { Bu-Olayan et al. } \\
\text { (2001) }\end{array}$ \\
\hline 6 & $\begin{array}{l}\text { Toxicological studies } \\
\text { (Toxicity test) }\end{array}$ & Kuwait & $\begin{array}{l}\text { Local mudskipper } P \text {. } \\
\text { waltoni }\end{array}$ & $\begin{array}{l}\text { Metals (cadmium, iron, } \\
\text { copper, zinc) }\end{array}$ & $\begin{array}{l}\text { Acute toxicity test for } \\
96 \mathrm{~h} \text { and ICP-MS } \\
\text { analysis }\end{array}$ & $\begin{array}{l}\text { Bu-Olayan and } \\
\text { Thomas (2008) }\end{array}$ \\
\hline 7 & $\begin{array}{l}\text { Toxicological studies } \\
\text { (Toxicity test) }\end{array}$ & Kuwait & $\begin{array}{l}\text { Local mullet } L \text {. } \\
\text { Klunzingeri }\end{array}$ & $\begin{array}{l}\text { Metals (nickel, iron, } \\
\text { cadmium, arsenic) }\end{array}$ & $\begin{array}{l}\text { Acute toxicity test for } \\
96 \mathrm{~h} \text { and Analytical } \\
\text { Hydra Jena (HS-55) }\end{array}$ & $\begin{array}{l}\text { Bu-Olayan et al. } \\
(2008)\end{array}$ \\
\hline 8 & $\begin{array}{l}\text { Toxicological studies } \\
\text { (Toxicity test) }\end{array}$ & Kuwait & $\begin{array}{l}\text { Blue crab } P \text {. pelagicus } \\
\text { and mollusc } T \text {. sulcarius }\end{array}$ & Total mercury & $\begin{array}{l}\text { Acute toxicity test for } \\
96 \mathrm{~h}\end{array}$ & $\begin{array}{l}\text { Bu-Olayan and } \\
\text { Thomas (2015) }\end{array}$ \\
\hline 9 & $\begin{array}{l}\text { Toxicological studies } \\
\text { (Toxicity test) }\end{array}$ & Kuwait & $\begin{array}{l}\text { Eggs and larvae of local } \\
\text { Hamoor E. coicoides }\end{array}$ & $\begin{array}{l}\text { Water accommodated } \\
\text { fraction of Kuwait crude oil } \\
\text { (monocyclic aromatic } \\
\text { hydrocarbons, total } \\
\text { petroleum hydrocarbons, } \\
\text { polycyclic aromatic } \\
\text { hydrocarbons) }\end{array}$ & $\begin{array}{l}\text { Acute toxicity test for } \\
24 \mathrm{~h}, 48 \mathrm{~h}, 72 \mathrm{~h}, 96 \\
\mathrm{~h} \text { and FT-IR, GC-MS } \\
\text { analysis }\end{array}$ & $\begin{array}{l}\text { Karam et al. } \\
(2014)\end{array}$ \\
\hline 10 & $\begin{array}{l}\text { Toxicological } \\
\text { techniques (Toxicity } \\
\text { test) }\end{array}$ & Kuwait & $\begin{array}{l}\text { Eggs and larvae of local } \\
\text { Hamoor E. coicoides }\end{array}$ & $\begin{array}{l}\text { Water accommodated } \\
\text { fraction of Kuwait crude oil } \\
\text { and oil dispersants } \\
\text { (Corexit }^{\circledR} \text { EC } 9500 A \text {, } \\
\text { Corexit }^{\circledR} \text { EC 9527A and } \\
\text { Slickgone }^{\circledR} \text { NS) }\end{array}$ & $\begin{array}{l}\text { Acute toxicity test for } \\
24 \text { h, } 48 \text { h, } 72 \text { h, } 96 \\
\text { h and RF- } 5301 \text { PC } \\
\text { SHIMADZU }{ }^{\circledR} \text { spec- } \\
\text { trofluorophotometer }\end{array}$ & $\begin{array}{l}\text { Karam et al. } \\
(2019)\end{array}$ \\
\hline 11 & $\begin{array}{l}\text { Toxicological studies } \\
\text { (Toxicity test) }\end{array}$ & $\begin{array}{l}\text { Kuwait \& Saudi } \\
\text { Arabia }\end{array}$ & Amphipod $R$. abronius & Petroleum hydrocarbons & $\begin{array}{l}\text { Acute toxicity test for } \\
96 \mathrm{~h} \text { and Infrared } \\
\text { spectrometry }\end{array}$ & $\begin{array}{l}\text { Randolph et al. } \\
\text { (1998) }\end{array}$ \\
\hline 12 & $\begin{array}{l}\text { Toxicological studies } \\
\text { (Toxicity test) }\end{array}$ & Saudi Arabia & $\begin{array}{l}\text { Corlas; Acropora sp., } \\
\text { Platygyra sp., Goniopora } \\
\text { sp., and Porites sp. }\end{array}$ & $\begin{array}{l}\text { Arabian light crude oil and } \\
\text { oil dispersant (Corexit 9527) }\end{array}$ & $\begin{array}{l}\text { Scanning electron } \\
\text { microscopy after } 24 \mathrm{~h} \\
\text { and } 120 \mathrm{~h} \text { of } \\
\text { exposure for } \\
\text { bleaching and growth } \\
\text { evaluation }\end{array}$ & $\begin{array}{l}\text { LeGore et al. } \\
\text { (1989) }\end{array}$ \\
\hline 13 & $\begin{array}{l}\text { Toxicological studies } \\
\text { (Toxicity test) }\end{array}$ & Saudi Arabia & $\begin{array}{l}\text { Chromogenic and } \\
\text { non-chromogenic } \\
\text { bacteria Flavobacterium \& } \\
\text { Pseudomonas groups }\end{array}$ & $\begin{array}{l}\text { Metals (arsenic, cadmium, } \\
\text { chromium, cobalt, copper, } \\
\text { iron, lead, manganese, } \\
\text { mercury, molybdenum, } \\
\text { nickel, silver, strontium, tin, } \\
\text { vanadium, zinc) }\end{array}$ & $\begin{array}{l}\text { Acute toxicity test for } \\
96 \mathrm{~h} \text { using direct agar } \\
\text { diffusion assay }\end{array}$ & Chandy (1998) \\
\hline 14 & $\begin{array}{l}\text { Toxicological studies } \\
\text { (Growth rate) }\end{array}$ & Saudi Arabia & Corals; P. lutea & Hydrocarbons & GC-MS & $\begin{array}{l}\text { Poulsen et al. } \\
(2006)\end{array}$ \\
\hline 15 & $\begin{array}{l}\text { Toxicological studies } \\
\text { (Toxicity test) }\end{array}$ & Qatar & $\begin{array}{l}\text { Local mullet fry } L \text {. } \\
\text { macrolepis }\end{array}$ & $\begin{array}{l}\text { Oil dispersants (Shell LTX, } \\
\text { Shell concentrate, Servo CD } \\
2000 \text { and Exxon OSD 9217) }\end{array}$ & $\begin{array}{l}\text { Acute toxicity test for } \\
72 \mathrm{~h}\end{array}$ & $\begin{array}{l}\text { El Samra et al. } \\
\text { (1986) }\end{array}$ \\
\hline
\end{tabular}


Table 1 (continued)

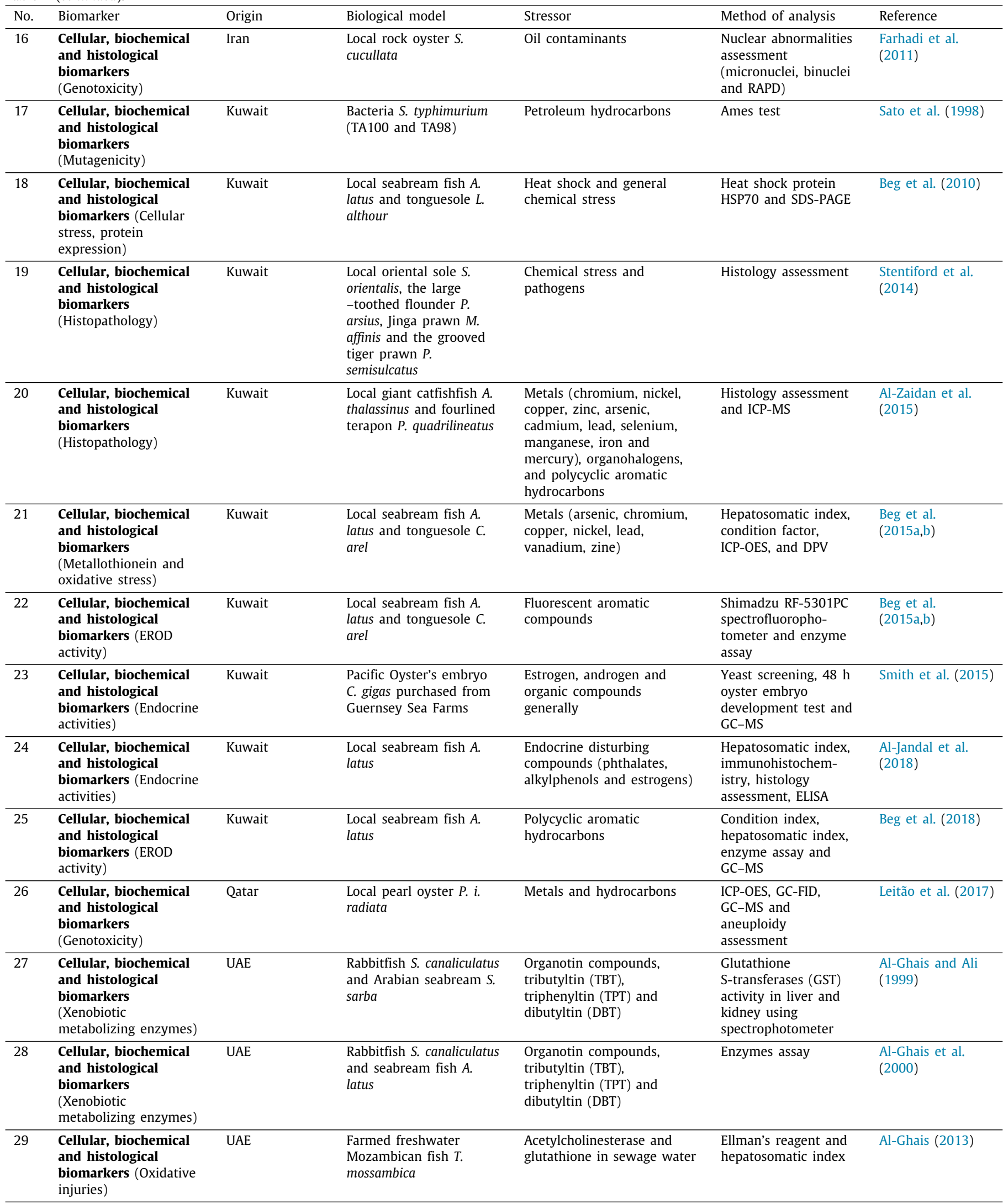

cytosolic carboxylesterases. However, the detoxification response of both species was inhibited by the presence of organotins, which supports the accepted theory that co-exposure to such compounds may lead to an enhancement of the toxicity of other common environmental contaminants (Al-Ghais et al., 2000). Similar findings were reported earlier by Al-Ghais and Ali (1999), who reported that $S$. canaliculatus was a more sensitive indicator 
Table 2

Reported values of LC50 (lethal concentration at which half of the population are killed) from acute toxicity tests in the Gulf.

\begin{tabular}{|c|c|c|}
\hline Species & $\mathrm{LC}_{50}$ values & Reference \\
\hline P. waltoni & $\begin{array}{l}\mathbf{L C}_{\mathbf{5 0}} \text { for } \mathbf{9 6} \mathbf{h} \\
\text { cadmium }=3.25 \mu \mathrm{g} / \mathrm{L} \\
\text { iron }=6.48 \mu \mathrm{g} / \mathrm{L} \\
\text { copper }=7.56 \mu \mathrm{g} / \mathrm{L} \\
\text { zinc }=12.21 \mu \mathrm{g} / \mathrm{L}\end{array}$ & $\begin{array}{l}\text { Bu-Olayan and } \\
\text { Thomas (2008) }\end{array}$ \\
\hline L. klunzingeri & $\begin{array}{l}\mathbf{L C}_{\mathbf{5 0}} \text { for } \mathbf{9 6 ~ h} \\
\text { nickel }=3.62 \& 3.21 \mu \mathrm{g} / \mathrm{L} \\
\text { iron }=5.75 \& 5.58 \mu \mathrm{g} / \mathrm{L} \\
\text { cadmium }=9.90 \& 9.80 \mu \mathrm{g} / \mathrm{L} \\
\text { arsenic }=13.22 \& 12.13 \mu \mathrm{g} / \mathrm{L} \\
{ }^{*} \text { Kuwait bay \& Kuwait coastal } \\
\text { waters respectively }\end{array}$ & $\begin{array}{l}\text { Bu-Olayan } \\
\text { et al. (2008) }\end{array}$ \\
\hline E. coicoides & $\begin{array}{l}\mathbf{L C}_{\mathbf{5 0}} \text { for } \mathbf{9 6} \mathbf{~ h} \\
\text { Water accommodated fraction } \\
\text { (WAF) of Kuwaiti crude oil = } \\
0.48 \mathrm{~g} / \text { oil } / 1 \text { seawater }\end{array}$ & $\begin{array}{l}\text { Karam et al. } \\
(2014)\end{array}$ \\
\hline $\begin{array}{l}\text { P. semisculcatus } \\
\text { P. semisculcatus } \\
\text { (Juveniles) } \\
\text { L. macrolepis } \\
\text { L. coronatus } \\
\text { M. canalifera } \\
\text { T. fusconigra } \\
\text { P. sulcatus } \\
\text { A. salina } \\
\text { E. mathaei }\end{array}$ & $\begin{array}{l}\mathbf{L C}_{\mathbf{5 0}} \text { for } \mathbf{9 6 ~ h} \\
\mathrm{Cu}>1.1 \mathrm{mg} / \mathrm{l}, \mathrm{Hg}=0.1 \mathrm{mg} / \mathrm{l} \\
\mathrm{Cu}=9.8 \mathrm{mg} / \mathrm{l}, \mathrm{Hg}<0.03 \mathrm{mg} / \mathrm{l} \\
\mathrm{Cu}=1.4 \mathrm{mg} / \mathrm{l}, \mathrm{Hg}=0.4 \mathrm{mg} / \mathrm{l} \\
\mathrm{Cu}=0.2 \mathrm{mg} / \mathrm{l}, \mathrm{Hg}=0.05 \mathrm{mg} / \mathrm{l} \\
\mathrm{Cu}=0.1 \mathrm{mg} / \mathrm{l}, \mathrm{Hg}=0.05 \mathrm{mg} / \mathrm{l} \\
\mathrm{Cu}=0.2 \mathrm{mg} / \mathrm{l}, \mathrm{Hg}=0.2 \mathrm{mg} / \mathrm{l} \\
\mathrm{Cu}=0.1 \mathrm{mg} / \mathrm{l}, \mathrm{Hg}=\mathrm{NA} \\
\mathrm{Cu}<0.6 \mathrm{mg} / \mathrm{l}, \mathrm{Hg}<0.03 \mathrm{mg} / \mathrm{l} \\
\mathrm{Cu}<0.6 \mathrm{mg} / \mathrm{l}, \mathrm{Hg}>0.03 \mathrm{mg} / \mathrm{l}\end{array}$ & $\begin{array}{l}\text { Jacob et al. } \\
(1980)\end{array}$ \\
\hline O. mykiss & $\begin{array}{l}\mathbf{L C}_{\mathbf{5 0}} \text { for } \mathbf{9 6} \mathbf{~ h} \\
\text { dispersant Pars1 }=47.76 \mathrm{mg} / \mathrm{l} \\
\text { dispersant OD4000 }=55.25 \\
\text { mg/l } \\
\text { oil+Pars1 }=491.42 \mathrm{mg} / \mathrm{l} \\
\text { oil+OD4000 }=722.21 \mathrm{mg} / \mathrm{l}\end{array}$ & $\begin{array}{l}\text { Bordbar et al. } \\
\text { (2006) }\end{array}$ \\
\hline L. vannamei & 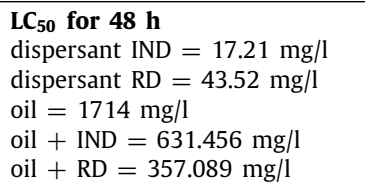 & $\begin{array}{l}\text { Delshad et al. } \\
\text { (2014) }\end{array}$ \\
\hline $\begin{array}{l}\text { E. coicoides } \\
\text { Embryonated } \\
\text { eggs, Larvae } \\
\text { hatched during } \\
\text { exposure, } \\
\text { Larvae }\end{array}$ & 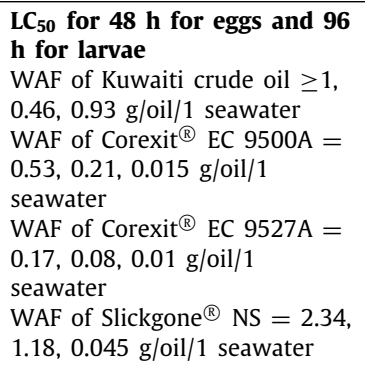 & $\begin{array}{l}\text { Karam et al. } \\
(2019)\end{array}$ \\
\hline L. macrolepis & $\begin{array}{l}\mathbf{L C}_{\mathbf{5 0}} \text { for } \mathbf{7 2} \mathbf{h} \\
\text { dispersant Exxon OSD } 9217= \\
27 \mathrm{mg} / \mathrm{l} \\
\text { dispersant Servo CD } 2000= \\
44 \mathrm{mg} / \mathrm{l} \\
\text { dispersant Shell concentrate }= \\
55 \mathrm{mg} / \mathrm{l} \\
\text { dispersant Shell LTX }=244 \\
\text { mg/l }\end{array}$ & $\begin{array}{l}\text { El Samra et al. } \\
\text { (1986) }\end{array}$ \\
\hline O. spilurus & $\begin{array}{l}\text { LC }_{\mathbf{5 0}} \text { for } \mathbf{2 4} \mathbf{~ h} \text { in contaminated } \\
\text { sediment } \\
\text { TPH and metals }(\mathrm{Cd}, \mathrm{Cr}, \mathrm{Cu}, \mathrm{Ni} \text {, } \\
\mathrm{Pb}, \mathrm{V}, \mathrm{Zn})=106 \mathrm{~g} / \mathrm{l} \\
\mathbf{L C}_{\mathbf{5 0}} \text { for } \mathbf{9 6} \mathbf{~ h} \text { in contaminated } \\
\text { sediment } \\
\text { TPH and metals }(\mathrm{Cd}, \mathrm{Cr}, \mathrm{Cu}, \mathrm{Ni} \text {, } \\
\mathrm{Pb}, \mathrm{V}, \mathrm{Zn})=332 \mathrm{~g} / \mathrm{l}\end{array}$ & $\begin{array}{l}\text { Beg et al. } \\
(2001)\end{array}$ \\
\hline $\begin{array}{l}\text { P. pelagicus and } \\
\text { T. sulcarius }\end{array}$ & $\begin{array}{l}\mathbf{L C}_{\mathbf{5 0}} \text { for } \mathbf{9 6} \mathbf{h} \\
\mathrm{Hg}=1.25 \text { to } 2.13 \mathrm{ng} / \mathrm{l}\end{array}$ & $\begin{array}{l}\text { Bu-Olayan and } \\
\text { Thomas (2015) }\end{array}$ \\
\hline
\end{tabular}

species for detecting the presence of organotins when compared to Sparus sarba.

The threat posed by chemical contaminants with endocrine disrupting potential is an area of growing concern in the Gulf (Smith et al., 2015; Saeed et al., 2017; Al-Jandal et al., 2018). Endocrine distrusting compounds (EDCs) can find their way into the Gulf's marine environment through both industrial and domestic effluents and pose a risk to exposed biota through the disruption of the normal functioning of hormonal systems, leading to behavioral disorders and reproductive cycle disturbances (Matthiessen et al., 2018). Studies of effluent discharges and coastal waters have identified the presence of phthalates, bisphenol-A, alkylphenols and estrogens in seawater and sediment samples collected from the coastline of Kuwait (Smith et al., 2015; Saeed et al., 2017). A widely used molecular quantitative approach to investigate EDCs is the yeast estrogen screen (YES) and yeast androgen screen (YAS) (Fang et al., 2000; Balsiger et al., 2010). The genetically modified recombinant yeast was introduced by Routledge and Sumpter (1996) by integrating a human estrogen receptor (hER) into the yeast genome. Regionally, Smith et al. (2015) employed the method to screen for the presence of EDCs in seawater collected from along the Kuwaiti coastline. While the level of response was considered low, the data demonstrated that contaminants with EDC like properties were detectable in both waste-water discharges and the receiving coastal waters.

The detection of petroleum-based contaminants in the bile of fish along with the induction of enzyme systems linked to their metabolism (e.g. CYP1A) have been used routinely as part of the monitoring tools to assess the exposure biota to hydrocarbonbased contaminants in marine monitoring programs (OSPAR, 2008; Viarengo et al., 2007; Wernersson et al., 2015; Vethaak et al., 2017). Studies in the Gulf have assessed the suitability of local species to be used in conjunction with bile metabolites (Beg et al., 2002; Al-Zaidan et al., 2015; Beg et al., 2015b, 2018) and the induction of EROD in fish liver (Beg et al., 2015b, 2018) as a biomarker of CYP1A activity and exposure to chemical contaminants known to induce such systems. Data for the region demonstrate that differences in species response and seasonality can be observed (Beg et al., 2015a,b, 2018). The degree of biomarker response tended to be relatively low compared to studies conducted elsewhere, which reflected the general degree of contamination by known inducers of these markers (Gevao et al., 2012; Lyons et al., 2015a; Nicolaus et al., 2017) and the limited regional baseline information available against which to compare species specific responses (Al-Zaidan et al., 2015; Beg et al., 2018).

The assessment of heat shock proteins (HSP) as a marker of cellular stress response has been used widely in aquatic studies as a biomarker of both biotic and abiotic stressors (Van der Oost et al., 2003; Roberts et al., 2010) Their suitability for use in seabream A. latus and demersal tonguesole Lesan althour, has been assessed in studies conducted in Kuwait (Beg et al., 2010). Seasonally linked expression of HSP70 was determined in liver, gill and muscle tissues. While data indicated expression-levels were linked to water temperature the authors also noted the potential of co-occurring pollutants (e.g. PAHs) to also influence expression (Beg et al., 2010).

Biological effect endpoints linked to metal exposure have also been the subject of a number of studies, given the potential for biota in the Gulf to be exposed to such contaminants (Naser, 2013; Cunningham et al., 2019). Bioaccumulation of metals in tissue can lead to cellular stress, such as oxidative injuries, and in response organisms can regulate levels of metallothionein (MT), low molecular weight proteins known to bind to free metal ions (see Wang et al., 2014 for review). In the Gulf, baseline studies have been undertaken using the sentinel species $A$. latus and $C$. 
arel collected from the field to investigate MT protein expression along with the induction of antioxidant enzymes in gill and liver to be used as biomarkers of metal exposure (Beg et al., 2015a). Similar to the data reported for HSP70, EROD activity and bile metabolites (Beg et al., 2010; Al-Zaidan et al., 2015; Beg et al., 2015a,b, 2018) there were differences observed between the two species and tissues studied, which is likely to reflect a combination of differences in exposure pathways and sensitivity to metal contamination.

In UAE, the biomarkers Acetylcholinesterase (AChE) reduced glutathione $(\mathrm{GSH})$ and hepatosomatic index (HSI) were used to screen for oxidative (GSH) and neurotoxicity (AChE) injury and hepatomegaly (HSI) in the freshwater fish Tilapia mossambica exposed to sewage effluent wastewater. The fish were cultured in either, clean fresh water, sewage effluent or sewage effluent followed immediately by 6 weeks of depuration in clean water (Al-Ghais, 2013). Measured response for all 3 markers was impacted by exposure to the sewage effluent, however fish exposed to the effluent and then depurated in clean water demonstrated a considerable degree of recovery, indicating the effects wastewater effluent can be mitigated by the use of depuration to detoxify exposed fish.

In the Gulf, bivalve molluscs have been employed as biological models due to their sessile nature, ability to bioaccumulate contaminants and wide-spread distribution across the region (de Mora et al., 2004, 2010). The rock oyster, Saccostrea cucullata has been used to assess the genotoxic risk posed by chemical contaminants at oil contaminated ports in Iran (Farhadi et al., 2011). The frequency of micronuclei (MN) and binucleated (BN) cells, along with the application of RAPD (Random Amplifying Polymorphism of DNA) assay in gill tissue of $S$. cucullata was undertaken in field collected samples to assess the genotoxic risk posed by environmental pollutants. Data indicated the suitability of the assays employed for determining site differences in genotoxic contaminant exposure and provides useful baseline data for the region (Farhadi et al., 2011). The pearl oyster, Pinctada imbricata radiata has also been used in chemical led monitoring programs across the Gulf (de Mora et al., 2004, 2010) and studies have demonstrated their suitability as a sentinel species when assessing genotoxic endpoints of chemical exposure (Leitão et al., 2017). Using cytogenetic markers the rate of aneuploidy (abnormal diploid chromosomal number) in gill tissue were shown to be higher in samples of P.i. radiata sampled from within Qatari ports when compared to oysters collected from sites with less anthropogenic activity. High concentrations of mercury and PAHs positively correlated with the recorded higher levels of aneuploidy at the sites studied (Leitão et al., 2017). Genomic resources are now starting to be made publicly for some of the key sentinel species used in the Gulf, including P.i. radiata (NCBI, 2019). The application of next generation sequencing technologies offers the potential to greatly increase in the availability of genomic information, facilitating the application of transcriptomic studies to investigate contaminate related effects in Gulf species.

Fish and shellfish diseases and pathologies, with a broad range of aetiologies, have increasingly been used as indicators of environmental stress since they provide a definite biological endpoint of historical exposure (Hinton et al., 1992; Stentiford et al., 2004). Histopathological field surveys have been undertaken in Kuwaiti waters using species commonly found in the Northern Gulf, including oriental sole Synaptura orientalis; large-toothed flounder Pseudorhombus arsius; Jinga prawn Metapenaeus affinis and grooved tiger prawn Penaeus semisulcatus, to provide a baseline of both infectious and contaminant related pathologies (Stentiford et al., 2014). The authors reported a generally low occurrence of many of the pathologies typically associated with contaminant exposure (e.g. pre-cancerous and cancerous lesions). However, several cases of intersex (ovotestis), which have previously been used as an indicator of exposure to EDCs (Matthiessen et al., 2018), were reported. Further work in Kuwaiti waters expanded this approach to the catfish species A. thalassinus and the Fourlined terapon Pelates quadrilineatus (Al-Zaidan et al., 2015). Similar to the findings of Stentiford et al. (2014), the histological assessment conducted by Al-Zaidan and co-workers reported a low prevalence and severity of lesions, indicating that the fish examined were generally free of pathologies commonly associated with contaminant exposure. It should be noted that little information on the migratory behavior of these species is currently published for the Gulf, therefore until such information exists it will be difficult to link any observed pathology to known sources of pollution. To address such issues caging studies have often been employed to reduce the uncertainty caused by fish movement prior to capture (Hylland et al., 2006). Immunohistochemistry and histopathology, in conjunction with bioassays for EDC exposure have also been applied to A. latus, in caging studies at sites close to known point sources of pollution ( $\mathrm{Al}$ Jandal et al., 2018). Following a relatively short term (2 week) in-situ exposure, fish were brought to the laboratory and assessed with a battery of biomarkers including tissue histopathology, Vtg plasma induction and Vtg expression via the immunohistochemical staining of liver sections (Al-Jandal et al., 2018). At the caging locations three major classes of ECDs (phthalates, alkylphenols, and estrogens) were also detectable in water and sediment samples analyzed at the time fish were caged at the study sites. Results of the biomarker and histological assessments indicated that even after a relatively short 2-week exposure period structural and biochemical alternations in hepatic tissue were detectable (Al-Jandal et al., 2018). Field and laboratory studies undertaken in Iran have also used A. latus as a bioindicator species to demonstrate the suitability of gill pathology to assess environmental pollution (Salamat et al., 2013; Hassanienezad et al., 2014) The studies supporting the suitability of this species to act as a bioindicator organism and described the key gill pathologies observed following a 3-week exposure regime to a concentration series of $\mathrm{HgCl}_{2}$ (Hassanienezad et al., 2014). Similar pathologies were observed in field collected $A$. latus, with the range and frequency of alterations linked to local environmental conditions (Salamat et al., 2013).

\section{Conclusions}

Countries across the Gulf have been subjected to increasing industrial/urban development, with the associated anthropogenic pressure this can place on its coastal ecosystems (Sheppard et al., 2010; Van Lavieren et al., 2011). Given the environmental extremes of the region many of the Gulf's marine species are likely to be already functioning close to their physiological limits (Sheppard et al., 2010). Therefore, it is clear to see why concern has been raised as to the additional role chemical pollution may play in further stressing the regions marine ecosystems (Naser, 2013; Al-Sarawi et al., 2015). While limited to a relatively small number of studies it is encouraging to see a growing body of research linking toxicological endpoints to chemical contamination and environmental stress in the Gulf. Studies to date have mainly focused on validating individual test species for toxicological or biological effects-based analysis and integrated studies, such as those adopting multiple biomarkers across a number of species, such as employed in other regions are lacking (Viarengo et al., 2007; Lehtonen et al., 2014; Vethaak et al., 2017). To further the development and application of biological effects tools for determining the risk posed by chemical contaminants to the Gulf's marine ecosystems the following work areas should be considered. 
- There is a requirement for a greater number of ecotoxicology test species to have established protocols validated for the harsh environmental conditions (e.g. salinity, temperature and UV) present in the Gulf. This should include expanding the array of species (from different taxa or those with different life traits, including studies that have chronic or reproductive endpoints) naturally resident in the Gulf. If species are to be used in field studies then their lifestyle should be suitable (e.g. benthic feeder, so in close contact with sediments) and migration movements well described. Ideally, they would also occur across the region, so to promote the development of Gulf wide monitoring and assessment programs, employing one or more common bioindicator species. Results of such studies should be published in the peer review literature to expand the pool of validated species and test protocols available to researchers.

- There is a paucity of genomic data and associated molecular tools for marine species that reside in the Gulf, and a concerted research effort is required to address this issue. Genomic methods have the potential, if used appropriately, to scientifically enhance (e.g. understanding the interaction between complex mixtures of contaminants and environmental variables) the toolbox available for monitoring the health status of marine systems (Van Aggelen et al., 2010; Bourlat et al., 2013).

- To date subcellular, cellular and biochemical biomarker studies in the region have been restricted to a small number of studies. It is widely known that certain biomarkers are influenced by abiotic factors, such as temperature and salinity (e.g. EROD). However, rarely do studies examine their response under environmental conditions as extreme as those encountered in the Gulf. Laboratory studies are required to validate their performance (e.g. using chemicals that have previously been widely characterized) to assess their suitability for use in this region. As for ecotoxicology tests such studies should be published or made available to the regional bodies (e.g. ROPME) to expand the suite of validated biomarkers and protocols available to researchers.

- Once sufficient data is available for a select set of commonly applied biological effects markers then effort should directed at developing Background Assessment Criteria (BACs) and Environmental Assessment Criteria (EACs) for these biomarkers as undertaken and employed in other regional monitoring programs such as OSPAR (Convention for the Protection of the Marine Environment of the North-East Atlantic) and MEDPOL (Program for the Assessment and Control of Marine Pollution in the Mediterranean) (Lyons et al., 2010; Davies and Vethaak, 2012; Vethaak et al., 2017).

- Unlike chemical analytical protocols, where interlaboratory calibration ring trials are often routinely undertaken (e.g. as part of formal accreditation procedures such as QUASIMEME), there is often a lack of Quality Assurance (QA) or Quality Control (QC) protocols in place for biological effects studies. Therefore, as this field develops within region, researchers should look to develop a database of $\mathrm{QA} / \mathrm{QC}$ procedures or establish interlaboratory ring trials to add to the validity of their data. Examples exist where ring trials for biological effect tools have been successful implemented to validate their use in routine monitoring programs (Kammann et al., 2013; BEQUALM, 2018).

The application of the above recommendations would be a significant step forward in our understanding on how pollutants affect an already stressed marine ecosystems like the Gulf. Moreover, the Gulf has been pointed out lately as a "living laboratory" for climate change (Wolanski et al., 2019). Indeed, being an extreme environment, it will be well suited to act as a relevant case study to investigate the combined effect of anthropogenic stressors and environmental changes on marine species.

\section{Declaration of competing interest}

The authors declare that they have no known competing financial interests or personal relationships that could have appeared to influence the work reported in this paper.

\section{Acknowledgment}

This publication was made possible by the NPRP award [NPRP 9-394-1-090 "The Pearl Oyster: from national icon to guardian of Qatar's marine environment"] from the Qatar National Research Fund (a member of Qatar Foundation). The findings herein reflect the work, and are solely the responsibility, of the authors.

\section{References}

Al-Ghais, S.M., 2013. Acetylcholinesterase, glutathione and hepatosomatic index as potential biomarkers of sewage pollution and depuration in fish. Mar. Pollut. Bull. 74 (1), 183-186. http://dx.doi.org/10.1016/j.marpolbul.2013.07. 005.

Al-Ghais, S.M., Ahmad, S., Ali, B., 2000. Differential inhibition of xenobiotic metabolizing carboxylesterases by organotins in marine fish. Ecotoxicol. Environ. Saf. 46, 258-264. http://dx.doi.org/10.1006/eesa.2000.1928.

Al-Ghais, S.M., Ali, B., 1999. Inhibition of glutathione s-transferase catalyzed xenobiotic detoxication by organotin compounds in tropical marine fish tissues. Bull. Environ. Contam. Toxicol. 62, 207-213. http://dx.doi.org/10. $1007 /$ s001289900861.

Al-Jandal, N., Saeed, T., Azad, I., Al-Subiai, S., Al-Zekri, W., Hussain, S., AlHasan, E., 2018. Impact of endocrine disrupting compounds in sewage impacted coastal area on seabream. Ecotoxicol. Environ. Saf. 150, 280-288. http://dx.doi.org/10.1016/j.ecoenv.2017.12.035.

Al-Majed, N., Mohammadi, H., Al-Ghadban, A., 2000. Regional reports of the state of marine environment. In: ROPME/GC-10/001/1. Revised By Al-Awadi, A. Regional Organization for the Protection of the Marine Environment

Al-Said, T., Al-Ghunaim, A., Rao, D.S., Al-Yamani, F., Al-Rifaie, K., Al-Baz, A., 2017. Salinity-driven decadal changes in phytoplankton community in the NW Arabian Gulf of Kuwait. Environ. Monit. Assess. 189, 268. http://dx.doi.org/ 10.1007/s10661-017-5969-4.

Al-Sarawi, H.A., Jha, A.N., Al-Sarawi, M.A., Lyons, B.P., 2015. Historic and contemporary contamination in the marine environment of Kuwait: An overview. Mar. Pollut. Bull. 100, 621-628. http://dx.doi.org/10.1016/j.marpolbul.2015. 07.052 .

Al-Sarawi, H.A., Jha, A.N., Baker-Austin, C., Al-Sarawi, M.A., Lyons, B.P., 2018. Baseline screening for the presence of antimicrobial resistance in $E$. coli isolated from Kuwait's marine environment. Mar. Pollut. Bull. 129, 893-898. http://dx.doi.org/10.1016/j.marpolbul.2017.10.044.

Al-Yamani, F., Yamamoto, T., Al-Said, T., Alghunaim, A., 2017. Dynamic hydrographic variations in northwestern arabian gulf over the past three decades: Temporal shifts and trends derived from long-term monitoring data. Mar. Pollut. Bull. 122, 488-499. http://dx.doi.org/10.1016/j.marpolbul.2017.06.056.

Al-Zaidan, A.S., Al-Sarawi, H.A., Massoud, M.S., Al-Enezi, M., Smith, A.J., Bignell, J.P., Green, M.J., Askem, C., Bolam, T.P.C., Barber, J.L., Bersuder, P., Lyons, B.P., 2015. Histopathology and contaminant concentrations in fish from Kuwait's marine environment. Mar. Pollut. Bull. 100 (2), 637-645. http://dx.doi.org/10.1016/j.marpolbul.2015.07.030

Balsiger, H., Roche, R., Lee, W., Cox, M., 2010. A four-hour yeast bioassay for the direct measure of estrogenic activity in wastewater without sample extraction, concentration, or sterilization. Sci. Total Environ. 408 (6), 1422-1429. http://dx.doi.org/10.1016/j.scitotenv.2009.12.027.

Barranger, A., Benabdelmouna, A., Dégremont, L., Burgeot, T., Akcha, F., 2015. Parental exposure to environmental concentrations of diuron leads to aneuploidy in embryos of the pacific oyster, as evidenced by fluorescent in situ hybridization. Aquat. Toxicol. 159, 36-43. http://dx.doi.org/10.1016/j.aquatox. 2014.11.011.

Beg, M.U., Al-Ghadban, A.N., 2003. Impact of draining of Iraqi marshes on sediment quality of Kuwait's Northern marine area. Bull. Environ. Contam. Toxicol. 71, 60-67. http://dx.doi.org/10.1007/s00128-003-0131-0.

Beg, M.U., Al-Jandal, N., Al-Subiai, S., Karam, Q., Husain, S., Butt, S.A., Ali, A., AlHasan, E., Al-Dufaileej, S., Al-Husaini, M., 2015a. Metallothionein, oxidative stress and trace metals in gills and liver of demersal and pelagic fish species from Kuwait's marine area. Mar. Pollut. Bull. 100 (2), 662-672. http://dx.doi.org/10.1016/j.marpolbul.2015.07.058.

Beg, M.U., Al-Muzaini, S., Saeed, T., Jacob, P.G., Beg, K.R., Al-Bahloul, M., AlMatrouk, K., Al-Obaid, T., Kurian, A., 2001. Chemical contamination and toxicity of sediment from a coastal area receiving industrial effluents in Kuwait. Arch. Environ. Contam. Toxicol. 41, 289-297. http://dx.doi.org/10. 1007/s002440010251. 
Beg, M.U., Al-Subiai, S.N., Al-Jandal, N., Butt, S.A., Beg, K.R., Al-Husaini, M., 2015b. Seasonal effect on biomarkers of exposure to petroleum hydrocarbons in fish from Kuwait's marine area. Mar. Pollut. Bull. 100 (2), 673-680. http: //dx.doi.org/10.1016/j.marpolbul.2015.09.017.

Beg, M.U., Al-Subiai, S., Beg, K.R., Butt, S.A., Al-Jandal, N., Al-Hassan, E., AlHusaini, M., 2010. Seasonal effect on heat shock proteins in fish from Kuwait bay. Bull. Environ. Contam. Toxicol. 84, 91-95. http://dx.doi.org/10.1007/ s00128-009-9908-0.

Beg, M.U., Butt, S.A., Al-Dufaileej, S., Karam, Q., Al-Sharrah, T.K., Saeed, T., 2018. Biomarkers in fish as a measure of the state of marine environment of Kuwait. Environ. Monit. Assess. 190, 325. http://dx.doi.org/10.1007/s10661018-6704-5.

Beg, M.U., Jacob, P.G., Al-Matrouk, K., Beg, K.R., Al-Bahloul, M., Saeed, T., 2002. Benzo-a-pyrene residues in liver and bile of fish following oral exposure. Environ. Contam. Toxicol. 68, 436-443. http://dx.doi.org/10.1007/ s001280273.

BEQUALM, 2018. http://www.bequalm.org/biomarkers.htm (accessed $15 / 10 / 2019)$.

Bjerkeng, B., Molvær, J., 2000. Water Exchange and Circulation of the Arabian Gulf - Preliminary Study of Suitability for Seawater Scrubber Discharges. In: Series NIVA-rapport, vol. 4282, Norsk institutt for vannforskning.

Bordbar, L., Oryan, S., Emtiyazjoo, M., Farhani, D., 2006. The effect and the toxicity of Iranian oil dispersant (Pars 1) on rainbow trout. Environ. Probl. Coast. Reg. 88, 79-88. http://dx.doi.org/10.2495/CENV060081.

Bouilly, K., Leitão, A., McCombie, H., Lapegue, S., 2003. Impact of atrazine on aneuploidy in Pacific Oysters, Crassostrea gigas. Environ. Toxicol. Chem. 22 (1), 219-223. http://dx.doi.org/10.1002/etc.5620220129.

Bourlat, S.J., Borja, A., Gilbert, J., Taylor, M.I., Davies, N., Weisberg, S.B., et al., 2013. Genomics in marine monitoring: new opportunities for assessing marine health status. Mar. Pollut. Bull. 74, 19-31. http://dx.doi.org/10.1016/ j.marpolbul.2013.05.042.

Bu-Olayan, A.H., Al-Hassan, R., Thomas, B.V., 2001. Trace metal toxicity to phytoplankton of Kuwait coastal waters. Ecotoxicology 10, 185-189. http: //dx.doi.org/10.1023/A:1016602329047.

Bu-Olayan, A.H., Thomas, B.V., 2005a. Assessment on biocides bioaccumulation in mullet Liza klunzingeri in Kuwaiti waters, off the Arabian Gulf. Am. J. Environ. Sci. 2 (3), 109-113. http://dx.doi.org/10.3844/ajessp.2006.109.113.

Bu-Olayan, A.H., Thomas, B.V., 2005b. Toxicity and bioaccumulation of heavy metals in mullet fish Liza klunzingeri (Mugilidae: Perciformes). Chem. Ecol. 21 (3), 191-197. http://dx.doi.org/10.1080/02757540500117342.

Bu-Olayan, A.H., Thomas, B.V., 2006. Brine srimp, Artemia fransicana as a tool to study biocides toxicity in Kuwait bay, off the Arabian Gulf. J. Appl. Sci. Environ. Sanit. 1, 1-7.

Bu-Olayan, A.H., Thomas, B.V., 2008. Trace metals toxicity and bioaccumulation in mudskipper Periophthalmus waltoni Koumans 1941 (Gobiidae: Perciformes). Turkish J. Fish. Aquat. Sci. 8, 215-218.

Bu-Olayan, A.H., Thomas, B.V., 2015. Combined toxicity of mercury and plastic wastes to crustacean and gastropod inhabiting the waters in Kuwait. J. Environ. Biol. 36, 1291-1296.

Bu-Olayan, A.H., Thomas, B.V., Al-Husaini, M.S., 2008. Trace metals toxicity to the body structures of mullet Liza Klunzingeri (Mugilidae: Perciformes). Int. J. Environ. Res. 2 (3), 249-254. http://dx.doi.org/10.22059/ijer.2010.200.

Burt, J., Lavieren, H., Feary, D., 2014. Persian gulf reefs: An important asset for climate science in urgent need of protection. Ocean Chall. 20, 49-56.

Chandy, J., 1998. Heavy metal tolerance in chromogenic and non-chromogenic marine bacteria from Arabian Gulf. Environ. Monit. Assess. 59, 321-330. http://dx.doi.org/10.1023/A:1006173722510.

Cunningham, P.A., Sullivan, E.E., Everett, K.H., Kovach, S.S., Rajan, A., Barber, M.C., 2019. Assessment of metal contamination in Arabian/Persian Gulf fish: A review. Mar. Pollut. Bull. 143, 264-283. http://dx.doi.org/10.1016/j.marpolbul. 2019.04.007.

Darwish, M.A., Mohtar, R., 2013. Qatar Water challenges. Desalin. Water Treat. 51 (1-3), 75-86. http://dx.doi.org/10.1080/19443994.2012.693582.

Davies, I.M., Vethaak, A.D., 2012. Integrated marine environmental monitoring of chemicals and their effects. ICES Cooperative Research Report No. 315, ISBN: 978-87-7482-120-5, p. 277.

Dawoud, M.A., Al Mulla, M.M., 2012. Environmental impacts of seawater desalination: Arabian Gulf case study. Int. J. Environ. Sustain. (ISSN: 1927-9566) 1 (3), 22-37.

Delshad, N., Emtyazjoo, M., Khezri, M., 2014. Toxicity effect of oil spill dispersants on Litopenaeus Vannamei. Int. J. Environ. Res. (ISSN: 1735-6865) 8 (4), 1027-1030.

Devlin, M.J., Breckels, M., Graves, C., Barry, J., Capuzzo, E., Huerta, F.P., AlAjmi, F., Al-Husain, M., LeQuesne, W., Lyons, B.P., 2019. Seasonal and temporal drivers influencing phytoplankton community in Kuwait marine waters, documenting a changing landscape in the Gulf. Front. Mar. Sci. 6, 141. http://dx.doi.org/10.3389/fmars.2019.00141.

Dougherty, W., Yates, D., Edson Pereira, J., Monaghan, A., Steinhoff, D., Ferrero, B., Wainer, I., Flores-Lopez, F., Galaits, S., Kucera, P., Glavan, J., 2019. The EnergyWater-Health Nexus under Climate Change in the United Arab Emirates - Impacts and Implications "Climate Change and Energy Dynamics in the Middle East". Springer
El Samra, M.I., Ibrahim, M.A., Ahmed, I.F., 1986. Acute toxicity of some oi dispersants to mullet fry (Liza macrolepis) of the Arabian Gulf. Qatar Univ. Sci. Bull. 6, 363-369.

Erftemeijer, P., Shuail, D.A., 2012. Seagrass habitats in the Arabian Gulf: distribution, tolerance thresholds and threats. Aquat. Ecosyst. Health Manage. 15 73-83. http://dx.doi.org/10.1080/14634988.2012.668479.

Fang, H., Tong, W., Perkins, R., Soto, A., Prechti, N., Sheehan, D., 2000. Quantitative comparisons of in vitro assays for estrogenic activities. Environ. Health Perspect. 108 (8), 723-729. http://dx.doi.org/10.1289/ehp.00108723.

Farhadi, A., Farahmand, H., Mirvaghefi, A., Khalili, B., 2011. A genotoxicological study in Persian Gulf on rock oyster (Soccostrea cucullata) using micronucle and RAPD assays. Int. J. Environ. Res. 5 (2), 567-572. http://dx.doi.org/10 22059/ijer.2011.342.

Freije, A.M., 2015. Heavy metal, trace element and petroleum hydrocarbon pollution in the Arabian Gulf: Review. J. Assoc. Arab Univ. Basic Appl. Sci. 17, 90-100. http://dx.doi.org/10.1016/j.jaubas.2014.02.001.

Gevao, B., Aba, A.A., Al-Ghadban, A.N., Uddin, S., 2012. Depositional history of polychlorinated biphenyls in a dated sediment core from the northwestern Arabian Gulf. Arch. Environ. Contam. Toxicol. 62, 549-556. http://dx.doi.org/ 10.1007/s00244-011-9739-y.

Hassanienezad, L., Safahieh, A., Salamat, N., Savari, A., Majd, N.E., 2014. Assessment of gill pathological responses in the tropical fish yellowfin seabream of Persian Gulf under mercury exposure. Toxicol. Rep. 1, 621-628. http: //dx.doi.org/10.1016/j.toxrep.2014.07.016

Hinton, D.E., Baumen, P.C., Gardener, G.C., Hawkins, W.E., Hendricks, J.D. Murchelano, R.A., Okhiro, M.S., 1992. Histopathological biomarkers. In: Huggett, R.J., Kimerle, R.A., Mehrle, P.M., Bergman, H.L. (Eds.), Biomarkers: Biochemical, Physiological and Histological Markers of Anthropogenic Stress. Lewis Publishers, MI, pp. 155-210.

Hutchinson, T.H., Lyons, B.P., Thain, J.E., Law, R.J., 2013. Evaluating legacy contaminants and emerging chemicals in marine environments using adverse outcome pathways and biological effects-directed analysis. Mar. Pollut. Bull. 74 (2), 517-525. http://dx.doi.org/10.1016/j.marpolbul.2013.06.012.

Hylland, K., Serigstad, B., Thain, J.E., 2006. In situ deployment of organisms and passive samplers during the BECPELAG workshop: introduction and summary. In: Hylland, K., Vethaak, A.D., Lang, T. (Eds.), Biological Effects of Contaminants in Marine Pelagic Ecosystems (ICES). SETAC Publications, pp. $167-170$.

Jacob, P.G., Zarba, M.A., Salem, A.A., 1980. Results of toxicity tests with marine organisms of Kuwaiti coast. Indian J. Fish. 27 (1-2), 111-112.

Kammann, U., Askem, C., Dabrowska, H., Grung, M., Kirby, M.F., Koivisto, P. Lucas, C., McKenzie, M., Meier, S., Robinson, C., Tairova, Z.M., Tuvikene, A., Vuorinen, P.J., Strand, J., 2013. Interlaboratory proficiency testing for measurement of the PAH metabolite 1-hydroxypyrene in fish bile for marine environmental monitoring. J. AOAC Int. 96 (3), 635-641. http://dx.doi.org 10.5740/jaoacint.12-080.

Kammann, U., Lang, T., Vobach, M., Wonsniok, W., 2005. Ethoxyresorufin-O deethylase (EROD) activity in dab (Limanda limanda) as biomarker for marine monitoring. Environ. Sci. Pollut. Res. 12 (3), 140-145. http://dx.doi.org/10. 1065/espr2004.12.228.

Karam, Q., Ali, M., Subrahmanyam, M., Abdul, K., Bentley, M., Beg, 2019. A comparative study on the effect of dispersed and undispersed Kuwait crude oil on egg hatching and larval survival of Epinephelus coioides. J. Environ. Biol. Orig. Res. 40 (2), 192-199. http://dx.doi.org/10.22438/jeb/40/2/MRN-836.

Karam, Q., Beg, M.U., Al-khabbaz, A., Al-Ballam, Z., Dakour, S., Al-Abdul Elah, K. 2014. Effect of water-accommodated fraction of Kuwait crude oil on developmental stages of orange- spotted grouper hamoor (Epinephelus coicoides). Int. J. Adv. Agric. Environ. Eng. 1 (1), 105-112.

Kirby, M.F., Lyons, B.P., Barry, R.J., 2007b. The toxicological impacts of oil and chemically dispersed oil: UV mediated phototoxicity and implications for environmental effects, statutory testing and response strategies. Mar. Pollut. Bull. 54 (4), 472-475. http://dx.doi.org/10.1016/j.marpolbul.2006.11.011.

Kirby, M.F., Smith, A.J., Rooke, J., Scott, A.P., Katsiadaki, I., 2007a. EthoxyresorufinO-deethylase (EROD) and vitellogenin (VTG) in flounder (Platichthys flesus): system interaction, crosstalk and implications for monitoring. Aquat. Toxicol. 81 (3), 233-244. http://dx.doi.org/10.1016/j.aquatox.2006.12.004.

Law, R., Hanke, G., Angelidis, M., Batty, J., Bignert, A., Dachs, J., Davies, I., Denga, A., Duffek, B., Herut, H., Hylland, K., Lepom, P., Leonards, P., Mehtonen, J., Piha, M., Roose, P., Tronczynski, J., Velikova, V., Vethaak, D., 2010 Marine strategy framework directive - task group 8 report - contaminants and pollution effects. EUR 24335 EN - Joint Research Centre Scientific and Technical Reports, Scientific and Technical Research SeriesOffice for Official Publications of the European Communities, Luxembourg, ISBN: 978-92-79-15648-9, p. 161. http://dx.doi.org/10.2788/85887.

Le Quesne, W.J.F., Baker-Austin, C., Verner-Jeffreys, D.W., Al-Sarawi, H.A., Balkhy, H.H., Lyons, B.P., 2018. Antimicrobial resistance in the Gulf Cooperation Council region: A proposed framework to assess threats, impacts and mitigation measures associated with AMR in the marine and aquatic Environ. Int. 121 (1), 1003-1010. http://dx.doi.org/10.1016/j.envint.2018.06 030. 
LeGore, S., Marszalek, D., Danek, L., Tomlinson, M., Hofmann, J., 1989. Effects of Chemically Dispersed Oil on Arabian Gulf Corals: A Field Experiment, Oil Spill Conference, Texas, 1989. Hunter Environmental Services Inc, Florida.

Lehtonen, K.K., Sundelin, B., Lang, T., Strand, J., 2014. Development of tools for integrated monitoring and assessment of hazardous substances and their biological effects in the Baltic sea. AMBIO 43, 69-81. http://dx.doi.org/10. 1007/s13280-013-0478-3.

Leitão, A., Al-Shaikh, I., Hassan, H., Ben Hamadou, R., Bach, S., 2017. First genotoxicity assessment of marine environment in Qatar using the local pearl oyster Pinctada radiata. Reg. Stud. Mar. Sci. 11, 23-31. http://dx.doi.org/10. 1016/j.rsma.2017.02.001.

Lyons, B.P., Barber, J.L., Rumney, H.S., Bolam, T.P.C., Bersuder, P., Law, R.J., Mason, C., Smith, A.J., Morris, S., Devlin, M.J., 2015a. Baseline survey of marine sediments collected from the State of Kuwait: PAHs, PCBs, brominated flame retardants and metal contamination. Mar. Pollut. Bull. 100 (2), 629-636. http://dx.doi.org/10.1016/j.marpolbul.2015.08.014.

Lyons, B.P., Bignell, J.P., Stentiford, G.D., Bolam, T.P.C., Rumney, H.S., Bersuder, P., Barber, J.L., Askem, C.E., Nicolaus, M.E.E., Maes, T., 2017. Determining good environmental status under the marine strategy framework directive: case study for descriptor 8 (chemical contaminants). Mar. Pollut. Bull. 124, 118-129. http://dx.doi.org/10.1016/j.marenvres.2015.12.010.

Lyons, B.P., Devlin, M.J., Hamid, S.A.A., Al-Otiabi, A.F., Al-Enezi, M., Massoud, M.S. Al-Zaidan, A.S., Smith, A.J., Morris, S., Bersuder, P., Barber, J.L., Papachlimitzou, A., Al-Sarawi, H.A., 2015b. Microbial water quality and sedimentary faecal sterols as markers of sewage contamination in Kuwait. Mar. Pollut Bull. 100 (2), 689-698. http://dx.doi.org/10.1016/j.marpolbul.2015.07.043.

Lyons, B.P., Thain, J.E., Stentiford, G., Hylland, K., Davies, I.M., Vethaak, A.D., 2010. Using biological effects tools to define good environmental status under the European Union marine strategy framework directive. Mar. Pollut. Bull. 60 (10), 1647-1651. http://dx.doi.org/10.1016/j.marpolbul.2010.06.005.

Marshall, C.D., Al Ansi, M., Dupont, J., Warren, C., Al Shaikh, I., Cullen, J., 2018. Large dugong (Dugong dugon) aggregations persist in coastal Qatar. Mar. Mamm. Sci. 34 (4), 1154-1163. http://dx.doi.org/10.1111/mms.12497.

Matthiessen, P., Allen, Y.T., Bamber, S., Craft, J., Hurst, Y.T., Hutchinson, T., Feist, S.W., Katsiadaki, I., Kirby, M.F., Robinson, C., Scott, A.P., Thain, J.E., Thomas, K.V., 2002. The impact of estrogenic and androgenic contamination on marine organisms in the United Kingdom - summary of the EDMAR programme. Mar. Environ. Res. 5 (3-5), 645-649. http://dx.doi.org/10.1016/ S0141-1136(02)00135-6.

Matthiessen, P., Wheeler, J.R., Weltje, L., 2018. A review of the evidence for endocrine disrupting effects of current-use chemicals on wildlife populations. Crit. Rev. Toxicol. 48, 3. http://dx.doi.org/10.1080/10408444.2017.1397099.

Moore, A.B.M., Almojil, D.A., Harris, M., Jabado, R., White, W.T., 2013. New biological data on the rare, threatened shark Carcharhinus leiodon (Carcharhinidae) from the Persian Gulf and Arabian Sea. Mar. Freshw. Res. 65, 327-332. http://dx.doi.org/10.1071/MF13160.

de Mora, S., Fowler, S.W., Wyse, E., Azemard, S., 2004. Distribution of heavy metals in marine bivalves, fish and coastal sediment in the Gulf and Gulf of Oman. Mar. Pollut. Bull. 49 (5-6), 410-424. http://dx.doi.org/10.1016/j. marpolbul.2004.02.029.

de Mora, S., Tolosa, I., Fowler, S.W., Villeneuve, J.-P., Cassi, R., Cattini, C., 2010. Distribution of petroleum hydrocarbons and organochlorinated contaminants in marine biota and coastal sediments from the ROPME sea area during 2005. Mar. Pollut. Bull. 60, 2323-2349. http://dx.doi.org/10.1016/j.marpolbul.2010. 09.021.

Naser, H.A., 2013. Assessment and management of heavy metal pollution in the marine environment of the Arabian Gulf: A review. Mar. Pollut. Bull. 72 (1), 6-13. http://dx.doi.org/10.1016/j.marpolbul.2013.04.030.

Naser, H., 2014. Marine ecosystem diversity in the Arabian Gulf: Threats and conservation. In: Grillo, Oscar (Ed.), Biodiversity - the Dynamic Balance of the Planet. In Tech Publishing 2014, pp. 297-328.

NCBI, 2019. De novo transcriptome assembly of the Qatari pearl oyster Pinctada imbricata radiata. https://www.ncbi.nlm.nih.gov/nuccore/ICPG00000000.1.

Nicolaus, E.E.M., Barry, J., 2015. Imposex in the dogwhelk (Nucella lapillus): 22year monitoring around England and Wales. Environ. Monit. Assess. 187 (12), 736. http://dx.doi.org/10.1007/s10661-015-4961-0.

Nicolaus, E.E.M., Wright, S.R., Barry, J., Bolam, T.P.C., Ghareeb, K., Ghaloom, M. Al-Kanderi, N., Harley, B.F.M., Le Quesne, W.J.F., Devlin, M.J., Lyons, B.P., 2017. Spatial and temporal analysis of the risks posed by total petroleum hydrocarbon and trace element contaminants in coastal waters of Kuwait. Mar. Pollut. Bull. 120, 422-427. http://dx.doi.org/10.1016/j.marpolbul.2017. 04.031

Van der Oost, R., Beyer, J., Vermeulen, N.P.E., 2003. Fish bioaccumulation and biomarkers in environmental risk assessment: a review. Environ. Toxicol. Pharmacol. 13 (2), 57-149. http://dx.doi.org/10.1016/S1382-6689(02)001266.

OSPAR, 2008. Co-Ordinated Environmental Monitoring Programme - Assessment Manual for Contaminants in Sediment and Biota. ISBN: 978-1-906840-20-4 Publication no. 379/2008.
Pilcher, N.J., Antonopoulou, M., Perry, L., Abdel-Moati, M.A., Al Abdessalaam, T.Z., Albeldawi, M., Al Ansi, M., Al-Mohannadi, S.F., Al Zahlawi, N., Baldwin, R., Chikhi, A., Das, H.S., Hamza, S., Kerr, O.J., Al Kiyumi, A., Mobaraki, A., Al Suwaidi, H.S., Al Suweidi, A.S., Sawaf, M., Tourenq, C., Williams, J., Willson, A., 2014. Identification of Important Sea Turtle Areas (ITAs) for hawksbill turtles in the Arabian Region. J. Exp. Mar. Biol. Ecol. 460, 89-99. http://dx.doi.org/10.1016/j.jembe.2014.06.009.

Poulsen, A., Burns, K., Lough, J., Brinkman, D., Delean, S., 2006. Trace analysis of hydrocarbons in coral cores from Saudi Arabia. Org. Geochem. 37, 1913-1930. http://dx.doi.org/10.1016/j.orggeochem.2006.07.011.

Pous, S., Carton, X.J., Lazure, P., 2012. A process study of the tidal circulation in the Persian Gulf. Open J. Mar. Sci. Sci. Res. Publishing 2, 131-140. http: //dx.doi.org/10.4236/ojms.2012.24016.

Randolph, C., Hardy, T.C., Fowler, S.C., Price, A.R.G., Pearson, W.H., 1998. Toxicity and persistence of nearshore sediment contamination following the 1991 Gulf War, The long-term environmental effects of the Gulf War. Environ. Int. 24, 33-42. http://dx.doi.org/10.1016/S0160-4120(97)00119-0.

Roberts, R.J., Agius, C., Saliba, Bossier, P., Sung, Y.Y., 2010. Heat shock proteins (chaperones) in fish and shellfish and their potential role in relation to fish health: a review. J. Fish Dis. 33 (10), 789-801. http://dx.doi.org/10.1111/j. 1365-2761.2010.01183.x.

Rodríguez, J.G., Tueros, I., Borja, A., Franco, J., Ignacio García Alonso, J., Garmendia, J.M., Muxika, I., Sariego, C., Valencia, V., 2009. Butyltin compounds, sterility and imposex assessment in Nassarius reticulatus (Linnaeus, 1758), prior to the 2008. European ban on TBT antifouling paints, within Basque ports and along coastal areas. Cont. Shelf Res. 29 (8), 1165-1173. http: //dx.doi.org/10.1016/j.csr.2009.01.005.

ROPME, 2003. State of Marine Environment Report- 2003. ROPME/GC-11/003 regional organization for the protection of the marine environment, Kuwait, p. 217

ROPME, 2013. State of Marine Environment Report- 2013. ROPME/ GC-16 /1-ii regional organization for the protection of the marine environment, Kuwait, p. 225

Routledge, E., Sumpter, J., 1996. Estrogenic activity of surfactants and some of their degradation products assessed using a recombinant yeast screen. Environ. Toxicol. Chem. 15 (3), 241-248. http://dx.doi.org/10.1002/etc. 5620150303.

Saeed, T., Al-Jandal, N., Abusam, A., Taqi, H., Al-Khabbaz, A., Zafar, J., 2017. Sources and levels of endocrine disrupting compounds (EDCs) in Kuwait's coastal areas. Mar. Pollut. Bull. 118, 407-412. http://dx.doi.org/10.1016/j. marpolbul.2017.03.010

Saeed, T., Al-Shimmari, F., Al-Mutairi, A., Abdullah, H., 2015. Spatial assessment of the sewage contamination of Kuwait's marine areas. Mar. Pollut. Bull. 94 (1-2), 307-317. http://dx.doi.org/10.1016/j.marpolbul.2015.01.030.

Salamat, N., Soleimani, Z., Safahieh, A., Savari, A., Ronagh, M.T., 2013. Using histopathological changes as a biomarker to trace contamination loading of Musa Creeks (Persian Gulf). Toxicol. Pathol. 41 (6), 913-920. http://dx.doi. org/10.1177/0192623312468515.

Sale, P.F., Feary, D., Burt, J.A., Bauman, A., Cavalcante, G., Drouillard, K., Kjerfve, B. Marquies, E., Trick, C., Usseglio, P., van Lavieren, H., 2011. The growing need for sustainable ecological management of marine communities of the Persian Gulf. Ambio 40, 4-17. http://dx doi.org/10.1007/s13280-010-0092-6.

Sato, S., Matsumura, A., Urushigawa, T., Metwally, M., Al-Muzaini, S., 1998. Type analysis and mutagenicity of petroleum oil extracted from sediment and soil samples in Kuwait. Environ. Int. 24 (1/2), 67-76. http://dx.doi.org/10.1016/ S0160-4120(97)00122-0.

Schøyen, M., Green, N.W., Hjermann, D.Ø., Tveiten, L., Beylich, B., Øxnevad, S., Beyer, J., 2019. Levels and trends of tributyltin (TBT) and imposex in dogwhelk (Nucella lapillus) along the Norwegian coastline from 1991 to 2017. Mar. Environ. Res. 144, 1-8. http://dx.doi.org/10.1016/j.marenvres. 2018.11.011

Sheppard, C., 2016. Coral reefs in the gulf are mostly dead now, but can we do anything about it?. Mar. Pollut. Bull. 105, 593-598. http://dx.doi.org/10. 1016/j.marpolbul.2015.09.031.

Sheppard, C., Al-Husiani, M., Al-Jamali, F., Al-Yamani, F., Baldwin, R., Bishop, J., Benzoni, F., Dutrieux, E., Dulvy, N.K., Durvasula, S.R.V., Jones, D.A., Loughland, R., Medio, D., Nithyanandan, M., Pilling, G.M., Polikarpov, I., Price, A.R.G., Purkis, S., Riegl, B., Saburova, M., Namin, K.S., Taylor, O., Wilson, S., Zainal, K., 2010. The Gulf: A young sea in decline. Mar. Pollut. Bull. 60, 13-38. http: //dx.doi.org/10.1016/j.marpolbul.2009.10.017.

Sheppard, C., Al-Husiani, M., Al-Jamali, F., Al-Yamani, F., Baldwin, R., Bishop, J., Benzoni, F., Dutrieux, E., Dulvy, N.K., Durvasula, S.R.V., Jones, D.A., Loughland, R., Medio, D., Nithyanandan, M., Pilling, G.M., Polikarpov, I., Price, A.R.G., Purkis, S., Riegl, B., Saburova, M., Namin, K.S., Taylor, O., Wilson, S., Zainal, K., 2012. Environmental concerns for the future of gulf coral reefs. In: Riegl, B., Purkis, S. (Eds.), Coral Reefs of the Gulf. In: Coral Reefs of the World, vol, 3, Springer. Dordrecht, http//dx doi.org/10,1007/978-94-007-3008-3 16.

Smith, A.J., McGowan, T., Devlin, M.J., Massoud, M.S., Al-Enezi, M., Al-Zaidan, A.S., Al-Sarawi, H.A., Lyons, B.P., 2015. Screening for contaminant hotspots in the marine environment of Kuwait using ecotoxicological and chemical screening techniques. Mar. Pollut. Bull. 100, 681-688. http://dx.doi.org/10. 1016/j.marpolbul.2015.08.043. 
Soliman, Y.S., Al Ansari, E.M.S., Wade, T.L., 2014. Concentration, composition and sources of PAHs in the coastal sediments of the exclusive economic zone (EEZ) of Qatar, Arabian Gulf. Mar. Pollut. Bull. 85, 542-548. http: //dx.doi.org/10.1016/j.marpolbul.2014.04.027.

Stentiford, G.D., Longshaw, M., Lyons, B.P., Jones, G., Green, M., Feist, S.W., 2004. Histopathological biomarkers in estuarine fish species for the assessment of biological effects of contaminants. Mar. Environ. Res. 55, 137-159. http: //dx.doi.org/10.1016/S0141-1136(02)00212-X.

Stentiford, G.D., Massoud, M.S., Al-Mudhhi, S., Al-Sarawi, M.A., Al-Enezi, M., Lyons, B.P., 2014. Histopathological survey of potential biomarkers for the assessment of contaminant related biological effects in species of fish and shellfish collected from Kuwait Bay, Arabian Gulf. Mar. Environ. Res. 98, 60-67. http://dx.doi.org/10.1016/j.marenvres.2014.03.005.

Subba, D.V., Al-Yamani, F., 1998. Phytoplankton ecology in the waters between Shatt Al-Arab and Straits of Hormuz, Arabian Gulf: A review. Plankton Biol. Ecol. 45 (2), 101-106.

Thain, J.E., Vethaak, A.D., Hylland, K., 2008. Contaminants in marine ecosystems: developing an integrated indicator framework using biological-effect techniques. ICES J. Mar. Sci. 65, 1508-1514. http://dx.doi.org/10.1093/icesjms/ fsn 120 .

United Nations, 2017. United Nations, Department of Economic and Social Affairs, Population Division (2017). World Population Prospects: The 2017 Revision.

Van Aggelen, G., Ankley, G., Baldwin, W., et al., 2010. Integrating omic technologies into aquatic ecological risk assessment and environmental monitoring: Hurdles, achievements, and future outlook. Environ. Health Perspect. 118 (1), 1-5. http://dx.doi.org/10.1289/ehp.0900985.

Van Lavieren, H., Burt, J., Feary, D.A., 2011. Managing the growing impacts of development on fragile coastal and marine ecosystems: lessons from the Gulf. A policy Report, United Nations University- Institute for Water, Environment, and Health, Hamilton, ON, Canada.
Vaughan, G.O., Burt, J.A., 2016. The changing dynamics of coral reef science in Arabia. Mar. Pollut. Bull. 105 (2), 441-458. http://dx.doi.org/10.1016/j. marpolbul.2015.10.052.

Vethaak, A.D., Davies, I.M., Thain, J.E., Gubbins, M.J., Martínez-Gómez, C., Robinson, C.D., Moffat, C.F., Burgeot, T., Maes, T., Wonsniok, W., Giltrap, M. Lang, T., Hylland, K., 2017. Integrated indicator framework and methodology for monitoring and assessment of hazardous substances and their effects in the marine environment. Mar. Environ. Res. 124, 11-20. http://dx.doi.org/10. 1016/j.marenvres.2015.09.010.

Viarengo, A., Lowe, D., Bolognesi, C., Fabbri, E., Koehler, A., 2007. The use of biomarkers in biomonitoring: a 2-tier approach assessing the level of pollutant-induced stress syndrome in sentinel organisms. Comp. Biochem. Physiol. C: Toxicol. Pharmacol. 146 (3), 281-300. http://dx.doi.org/10.1016/j. cbpc.2007.04.011.

Wang, W., Mao, H., Ma, D., Yang, W., 2014. Characteristics, functions, and applications of metallothionein in aquatic vertebrates. Front. Mar. Sci. 1, 34. http://dx.doi.org/10.3389/fmars.2014.00034.

Wernersson, A.-S., 2003. Predicting petroleum phototoxicity. Ecotoxicol. Environ. Saf. 54, 355-365.

Wernersson, A.-S., Carere, M., Maggie, C., Tusil, P., Soldan, P., James, A. Sanchez, W., Dulio, V., Broeg, K., Reifferscheid, G., Buchinger, S., Maas, H., Van Der Grinten, E., O’Toole, S., Ausili, A., Manfra, L., Marziali, L., Polesello, S. Lacchetti, I., Mancini, L., Lilja, K., Linderoth, M., Lundeberg, T., Fjällborg, B., Porsbring, T., Larsson, D.G.J., Bengtsson-Palme, J., Förlin, L., Kienle, C., Kunz, P., Vermeirssen, E., Werner, I., Robinson, C.D., Lyons, B., Katsiadaki, I., Whalley, C., den Haan, K., Messiaen, M., Clayton, H., Lettieri, T., Carvalho, R.N., Gawlik, B.M., Hollert, H., Di Paolo, C., Brack, W., Kammann, U., Kase, R. 2015. The european technical report on aquatic effect-based monitoring tools under the water framework directive. Environ. Sci. Eur. 27 (7), 1-11. http://dx.doi.org/10.1186/s12302-015-0039-4.

Wolanski, E., Day, J.W., Elliott, M., 2019. Coasts and estuaries. In: The Future. Elsevier publisher, ISBN: 978-0-12-814003-1, p. 702 